\title{
Characterization of on-road vehicle emissions in the Mexico City Metropolitan Area using a mobile laboratory in chase and fleet average measurement modes during the MCMA-2003 field campaign
}

\author{
M. Zavala ${ }^{1}$, S. C. Herndon ${ }^{2}$, R. S. Slott ${ }^{1}$, E. J. Dunlea ${ }^{1, *}$, L. C. Marr ${ }^{1}{ }^{* *}$, J. H. Shorter ${ }^{2}$, M. Zahniser ${ }^{2}$, \\ W. B. Knighton ${ }^{3}$, T. M. Rogers ${ }^{3}$, C. E. Kolb ${ }^{2}$, L. T. Molina ${ }^{1,4}$, and M. J. Molina ${ }^{1, * * *}$ \\ ${ }^{1}$ Department of Earth Atmospheric and Planetary Sciences, Massachusetts Institute of Technology, Cambridge, MA, USA \\ ${ }^{2}$ Center for Atmospheric and Environmental Chemistry, Aerodyne Research Inc., Billerica, MA, USA \\ ${ }^{3}$ Department of chemistry and Biochemistry, Montana State University, Bozeman, MT, USA \\ ${ }^{4}$ Molina Center for Energy and the Environment, San Diego, CA, USA \\ *now at: Cooperative Institute for Research in Environmental Sciences, University of Colorado, Boulder, CO, USA \\ ** now at: Department of Civil and Environmental Engineering, Virginia Tech. Blacksburg, VA, USA \\ **** now at: Department of Chemistry and Biochemistry, University of California, San Diego, USA
}

Received: 30 January 2006 - Published in Atmos. Chem. Phys. Discuss.: 12 June 2006

Revised: 14 September 2006 - Accepted: 21 October 2006 - Published: 8 November 2006

\begin{abstract}
A mobile laboratory was used to measure onroad vehicle emission ratios during the MCMA-2003 field campaign held during the spring of 2003 in the Mexico City Metropolitan Area (MCMA). The measured emission ratios represent a sample of emissions of in-use vehicles under real world driving conditions for the MCMA. From the relative amounts of $\mathrm{NO}_{\mathrm{x}}$ and selected VOC's sampled, the results indicate that the technique is capable of differentiating among vehicle categories and fuel type in real world driving conditions. Emission ratios for $\mathrm{NO}_{\mathrm{x}}, \mathrm{NO}_{\mathrm{y}}, \mathrm{NH}_{3}, \mathrm{H}_{2} \mathrm{CO}$, $\mathrm{CH}_{3} \mathrm{CHO}$, and other selected volatile organic compounds (VOCs) are presented for chase sampled vehicles in the form of frequency distributions as well as estimates for the fleet averaged emissions. Our measurements of emission ratios for both CNG and gasoline powered "colectivos" (public transportation buses that are intensively used in the MCMA) indicate that - in a mole per mole basis - have significantly larger $\mathrm{NO}_{\mathrm{x}}$ and aldehydes emissions ratios as compared to other sampled vehicles in the MCMA. Similarly, ratios of selected VOCs and $\mathrm{NO}_{\mathrm{y}}$ showed a strong dependence on traffic mode. These results are compared with the vehicle emissions inventory for the MCMA, other vehicle emissions measurements in the MCMA, and measurements of on-road emissions in U.S. cities. We estimate $\mathrm{NO}_{\mathrm{x}}$ emissions as $100600 \pm 29200$ metric tons per year for light duty gasoline vehicles in the
\end{abstract}

Correspondence to: M. Zavala

(miguelz@mit.edu)
MCMA for 2003. According to these results, annual $\mathrm{NO}_{\mathrm{x}}$ emissions estimated in the emissions inventory for this category are within the range of our estimated $\mathrm{NO}_{\mathrm{x}}$ annual emissions. Our estimates for motor vehicle emissions of benzene, toluene, formaldehyde, and acetaldehyde in the MCMA indicate these species are present in concentrations higher than previously reported. The high motor vehicle aldehyde emissions may have an impact on the photochemistry of urban areas.

\section{Introduction}

Emissions from mobile sources in megacities represent a major contribution to the degradation of air quality at local and regional scales. They contribute to a primary and secondary air pollutant burden that can threaten human health, damage ecosystems and influence climate (Molina and Molina, 2004; Molina et al., 2004).

Mobile emissions are generally quantified in emissions inventories based on activity factors estimated from a vehicle census or traffic counts, and emissions factors obtained from vehicle exhaust measurements, input into individual vehicle or fleet emission models (NARSTO, 2005). Despite the significance of mobile emissions in large urban environments, their estimation is highly uncertain for most species, mainly due to the large inter-vehicle variability of the parameters that affect emission rates. Similarly, there are numerous factors

Published by Copernicus GmbH on behalf of the European Geosciences Union. 
that affect the variability in emissions across different vehicles types. These include factors that affect the internal combustion efficiency in the vehicle, and therefore its engine's emission characteristics, such as engine type and size, fuel composition, and combustion temperature and pressure. The character and maintenance of fuel delivering and emission control systems (or lack thereof) significantly affect which engine emissions exit the tailpipe. Traffic modes, road conditions, vehicle maintenance practices, driving behavior and other vehicle operating conditions can significantly affect vehicle emissions (Popp et al., 1999). The influence of all these factors highlights the need for measurement techniques that capture real-world vehicle emissions to validate emission inventories.

Several techniques have been developed to measure vehicle emissions both in laboratory testing and in real world driving conditions. These include measurement techniques using chassis dynamometer studies (Whitfield et al., 1998; Yanowitz et al., 1999), traffic tunnel integration studies (Kirchstetter et al., 1999), cross-road remote-sensing studies at tunnels and other fixed sites (Bishop et al., 1989; Jiménez et al., 2000; Schifler et al., 2005), and Portable Emission Measurement System (PEMS) methods (Cadle et al., 2002). Real-world driving emissions measurement techniques may differ from dynamometer based testing techniques in several ways. Carefully controlled, but limited environmental conditions and driving patterns are typically used in chassis dynamometer studies and typically a relatively small number of vehicles are tested.

Real world emission measurement techniques typically sample a much larger number of vehicles, but may do so under a limited range of driving states. Tunnel studies sample hundreds to thousands of vehicles, but are typically limited to fleet average emission values, although some differentiation between light duty and heavy duty vehicle emissions can be obtained when data for tunnel tubes that exclude heavy duty vehicles are compared with comparable mixed traffic tunnel data. Remote sensing measurement techniques typically sample emissions from vehicles with a wide range of ages, models, maintenance and operational histories, but the sampling time is relatively short $(\sim 0.1 \mathrm{~s})$ and the range of driving states sampled is usually limited. On-board or trailer mounted PEMS instrumentation can characterize some emissions over a full range of on-road driving states, but are typically deployed on a small number of vehicles in any study. Detailed descriptions of these techniques and a review of their strengths and limitations for determining mobile emission factors are given elsewhere (e.g. Wenzel et al., 2000). As mobile emission inventories should accurately represent real world vehicle fleets and driving conditions, on-road measurement techniques that interrogate a wide range of vehicles over a full complement of drive states can make important contributions to this goal.

In recent years, additional techniques for the measurement of vehicle emissions under real-world driving conditions us- ing fast response measurements in on-road mobile laboratories have been applied in urban areas (Kittelson et al., 2000; Vogt et al., 2003; Kolb et al., 2004; Canagaratna et al., 2004; Herndon et al., 2005a, b; Shorter et al., 2005; Pirjola et al., 2004; Giechaskiel et al., 2005). In the chase technique, a mobile laboratory repeatedly samples the emissions of a target vehicle. Our implementation of this technique makes use of the fast time response and high sensitivity of laser spectroscopic instruments and other fast response trace gas measurement techniques for repeatedly intercepting and measuring the turbulent exhaust plume of the target vehicle. Similar to the traditional remote sensing studies, ratios of a given species to $\mathrm{CO}_{2}$, used as a tracer of combustion, are obtained during the analysis and the results indicate the number of molecules of the pollutants of interest per $\mathrm{CO}_{2}$ molecules emitted. In addition to the chase technique, which focuses on a series of selected individual vehicles within a given vehicular class, fleet average on-road emissions can be obtained by processing randomly intercepted vehicle plumes from surrounding traffic (both co-flowing and opposing lanes). In this fleet average mode, even merged plumes from multiple vehicles can be processed and included.

In this study, emission ratios for selected individual vehicles as well as fleet average fuel-use-based vehicle exhaust emissions from mobile laboratory data are deduced from onroad measurements. In the fleet average mode the mobile laboratory measured on-road ambient air mixed with emissions of the surrounding vehicles. Successful application of this method requires a large sample size of these mixed emission periods and a sampling time long enough such that the number of sampled vehicles is large enough to include a representative number of high emitters. Care must also be taken to avoid situations where the intercepted plumes are dominated by a few nearby vehicles for significant portions of the sampling period. On the basis of the central limit theorem, the emission averages should then be normally distributed if the samples are unbiased and sufficiently large.

MCMA-2003 was an extensive field campaign held during the spring of 2003 in the Mexico City Metropolitan Area (MCMA) designed to enhance the understanding of the physico-chemical transformations of emissions at the urban scale and improve air quality modeling validation activities (Molina et al., 2002). The five-week campaign included a Supersite at the National Center for Environmental Research and Training (Centro Nacional de Investigación y Capacitación ambiental, CENICA), near the center of the city, as well as continuous sampling at other peripheral sites. Measurements were obtained for most important meteorological variables (de Foy et al., 2005, 2006a, b), ground level and vertical profiles of several chemical species in gas and aerosol phases and samplings at boundary sites for a better characterization of the background concentration levels (Barnard et al., 2005; Johnson et al., 2005; Salcedo et al., 2006; Shirley et al., 2006; Volkamer et al., 2005). A preliminary two week deployment in February 2002 of an older 
version of the mobile laboratory was used to make initial onroad measurements in Mexico City in order to develop vehicle exhaust measurement techniques and survey the emission levels of selected pollutants as well as their ambient background concentrations.

The MCMA-2003 field campaign featured the use of a new mobile laboratory equipped with fast time response instrumentation to measure the emissions from on-road, in use vehicles in the MCMA. This version of the mobile lab and the measurement modes used during MCMA-2003 have been detailed in Kolb et al. (2004). In this work we present the analysis of the emission ratios obtained with chase and fleet average measurement modes during the MCMA-2003 field campaign. We present the analysis of mobile emission ratios for $\mathrm{NO}_{\mathrm{x}}, \mathrm{NO}_{\mathrm{y}}, \mathrm{NH}_{3}, \mathrm{H}_{2} \mathrm{CO}, \mathrm{CH}_{3} \mathrm{CHO}$, and other selected VOCs for chase sampled vehicles and fleet averaged emissions. The results are compared with the corresponding emissions inventory for the MCMA, other vehicle emissions measurements in the MCMA, and measurements of on-road emissions in U.S. cities.

\section{Experimental methods}

The mobile laboratory deployed during the MCMA-2003 field campaign was equipped with several high time resolution and high sensitivity instruments (Kolb et al., 2004). As described in Table 1, these included Tunable Infrared Laser Differential Absorption Spectrometers (TILDAS) for measuring selected gaseous pollutants, a Proton Transfer Reaction Mass Spectrometry (PTR-MS) for measuring selected volatile organic compounds (VOCs), a commercial $\mathrm{NO} / \mathrm{NO}_{\mathrm{y}}$ chemiluminescent detector modified for fast response measurements, and a Licor Non-Dispersive Infrared (NDIR) instrument for $\mathrm{CO}_{2}$. Other instruments on board the mobile laboratory included a Global Positioning System (GPS), a sonic anemometer attached close to the laboratory sampling port to detect "tailwind" conditions that might create sampled air volumes contaminated with the mobile lab's engine or onboard generator exhaust and a video camera used to obtain the target vehicle information. The mobile laboratory's velocity and acceleration were measured and recorded continuously during the experiment along with local atmospheric parameters including pressure, temperature, and relative humidity.

VOCs emissions are of particular interest in this study; all the reported VOCs were measured with the PTR-MS system, except for $\mathrm{H}_{2} \mathrm{CO}$ that was measured with the TILDAS instrument. TILDAS instruments have been successfully employed in several field campaigns for measuring trace gas species (Zahniser et al., 1995; Jiménez et al., 1999, 2000) and for measuring emissions from passenger buses using the chase technique (Herndon et al., 2005a; Shorter et al., 2005). $\mathrm{H}_{2} \mathrm{CO}$ and $\mathrm{NO}_{2}$ were measured using a lead salt tunable diode lasers TILDAS instruments and $\mathrm{NH}_{3}$ measure- ments were obtained using a quantum cascade laser in the TILDAS system. The PTR-MS system (Ionicon Analytic GMBH) was applied for measuring vehicle emissions during on-road chase events for the first time during this study. It was used to measure selected oxygenated, olefinic, and aromatic VOCs with proton affinities larger than water vapor via ionization through their reaction with $\mathrm{H}_{3} \mathrm{O}^{+}$. The resulting ions are detected by mass spectrometry at high time resolution and selectivity. Data processing and validation methods for VOCs measured with the PTR-MS system during the MCMA-2003 field campaign are reported in Rogers et al. (2006). $\mathrm{NO}$ and $\mathrm{NO}_{\mathrm{y}}$ measurements were obtained with a chemiluminescent instrument using a molybdenum oxide converter modified for high frequency $\mathrm{NO}_{\mathrm{y}}$ sampling (Dunlea et al., 2004). Although in principle the measured $\mathrm{NO}_{\mathrm{y}}$ captures all reactive nitrogen oxides species, the contribution from reservoir and terminal species such as PAN, $\mathrm{HNO}_{3}$, and organic nitrates, is likely minimal to the overall fresh emitted $\mathrm{NO}_{\mathrm{y}}$ concentration due to the short time (few seconds) between the emissions of $\mathrm{NO}$ and $\mathrm{NO}_{2}$ and their sampling by the mobile laboratory.

High time resolution instrumentation provides invaluable information on the emission exhaust characteristics of individual on-road vehicles. Indeed, this is the property that allows the chasing technique to capture the variability from the turbulent exhaust plumes that are quickly diluted in the surrounding air. In the chasing technique, the high time response instruments are used to measure the emission exhausts of the targeted vehicle through a sampling port localized at the driver's front side of the mobile lab. The sampled air is then delivered to the various instruments on board. Figure 1 shows an example of a sampling period during the chase of a gasoline vehicle. The sampled signals are correlated with $\mathrm{CO}_{2}$, a combustion tracer, if they are emitted by a target vehicle's exhaust. An emission ratio is obtained by scaling the measured species to the exhaust $\mathrm{CO}_{2}$ measured immediately behind the chased vehicle. As an example of this procedure, Fig. 1 also shows the obtained correlation obtained for the sampled species with $\mathrm{CO}_{2}$ for the same period.

This sampling technique interrogates vehicle exhaust plumes diluted with on-road background air; respective amounts of exhaust plume and background pollutant concentrations are determined by comparing background pollutant concentrations measured just before and after plume encounters with those inside exhaust plumes. In this work, we assume equal dilution for all of the different measured species. Therefore, the dilution experienced by a given emitted species will be equal to the dilution experienced by $\mathrm{CO}_{2}$, and it cancels in the ratio of excess pollutant (plume - background) divided by excess $\mathrm{CO}_{2}$ (plume - background). The equal dilution assumption is a very good approximation for the gaseous species in general but may not hold for very short-lived species (less than $\sim 1 \mathrm{~s}$ ) due to the potential chemical transformations occurring before sampling. 
Table 1. Instrumentation on board the Aerodyne mobile laboratory used during the MCMA 2002 and MCMA-2003.

\begin{tabular}{|c|c|c|c|}
\hline Instrumentation & Measures & Detection level & $\begin{array}{l}\text { Sampling } \\
\text { frequency }\end{array}$ \\
\hline $\begin{array}{l}\text { Proton Transfer Reaction Mass Spectrometer (PTR- } \\
\text { MS) }{ }^{\mathrm{a}}\end{array}$ & $\begin{array}{l}\text { Methanol, acetaldehyde, benzene, } \\
\text { toluene, MTBE, etc. }\end{array}$ & $1-5 \mathrm{ppb}$ & $\sim 1 \mathrm{~s}$ \\
\hline \multirow{4}{*}{$\begin{array}{l}\text { Tunable Infrared Laser Differential Absorption Spec- } \\
\text { troscopy (TILDAS) }\end{array}$} & NO & $1.1 \mathrm{ppb}$ & $1 \mathrm{~s}$ \\
\hline & $\mathrm{NO}_{2}$ & $700 \mathrm{ppt}$ & $1 \mathrm{~s}$ \\
\hline & $\mathrm{H}_{2} \mathrm{CO}$ & $1.2 \mathrm{ppb}$ & $1 \mathrm{~s}$ \\
\hline & $\mathrm{NH}_{3}$ & $600 \mathrm{ppt}$ & $1 \mathrm{~s}$ \\
\hline \multirow[t]{5}{*}{ Aerosol Mass Spectrometer $(\mathrm{AMS})^{\mathrm{c}}$} & Nitrate & $0.04 \mu \mathrm{g} \mathrm{m}^{-3}$ & $4 \mathrm{~s}$ \\
\hline & Sulfate & $0.06 \mu \mathrm{g} \mathrm{m}^{-3}$ & $4 \mathrm{~s}$ \\
\hline & Ammonium & $0.2 \mu \mathrm{g} \mathrm{m}^{-3}$ & $4 \mathrm{~s}$ \\
\hline & Organics & $0.8 \mu \mathrm{g} \mathrm{m}^{-3}$ & $4 \mathrm{~s}$ \\
\hline & Chloride & $0.04 \mu \mathrm{g} \mathrm{m}^{-3}$ & $4 \mathrm{~s}$ \\
\hline $\begin{array}{l}\text { Non-Dispersive Infrared instruments (NDIR) unit } \\
(\text { LICOR) })^{\mathrm{d}}\end{array}$ & $\mathrm{CO}_{2}$ & $0.2 \mathrm{ppm}$ & $1 \mathrm{~s}$ \\
\hline Aethalometer (Magee Scientific AE-16) & Black carbon & $0.1 \mu \mathrm{g} \mathrm{m}^{-3}$ & $1 \mathrm{~min}$ \\
\hline Photoemission aerosol sensor (EcoChem PAS 2000) & Particulate PAH & $10 \mathrm{ng} \mathrm{m}^{-3}$ & $10 \mathrm{~s}$ \\
\hline Chemiluminescence & $\mathrm{NO}_{\mathrm{x}}, \mathrm{NO}_{\mathrm{y}}$ & $0.4 \mathrm{ppb}$ & 1 to $10 \mathrm{~s}$ \\
\hline Aerosol photometer (TSI DustTrak) & $\mathrm{PM}_{2.5}$ & $1 \mu \mathrm{g} \mathrm{m}^{-3}$ & $1 \mathrm{~s}$ \\
\hline Condensation Particle Counter (CPC) & $10-100 \mathrm{~nm}$ particle number density & $0.01 \mathrm{part} / \mathrm{cm}^{3}$ & $2-3 s$ \\
\hline
\end{tabular}

a Only those components having proton affinities greater than water are detected using this technique which includes most oxygenated and unsaturated hydrocarbons.

${ }^{\mathrm{b}} \mathrm{H}_{2} \mathrm{CO}$ was detected using a pair of absorptions lines at 1774.67 and $1774.83 \mathrm{~cm}^{-1}$. Two relatively weak water lines bracket these features, and a very small water line is present in the gap between. The diode used for $\mathrm{NO}_{2}$ was operated at approximately $1606 \mathrm{~cm}^{-1}$ and $\mathrm{NO}^{2}$ approximately $1900 \mathrm{~cm}^{1}$. As operated during these measurements, the $1 \mathrm{~s} \mathrm{rms} \mathrm{precisions} \mathrm{for} \mathrm{H}_{2} \mathrm{CO}$ (diode 1 ) was normally less than 1.2 ppbv. For $\mathrm{NO}_{2}$ (diode 2) the $1 \mathrm{~s} \mathrm{rms}$ precision was 0.8 ppbv. $\mathrm{NH}_{3}$ was operated with a quantum cascade laser at approximately $960 \mathrm{~cm}^{-1}$.

$\mathrm{c}$ The detection limits from individual species were determined by analyzing periods in which ambient filtered air was sampled and are reported as three times the standard deviation of the measured mass concentration during those periods.

$\mathrm{d}$ The Licor-6262 non-dispersive infrared absorption instrument detects $\mathrm{CO}_{2}$ absorption in the $4.3 \mu \mathrm{m}$ band. Additional details regarding its performance in this application can be found elsewhere (Herndon et al., 2004). The measured response time of the Licor instrument to flooding the inlet tip with $\mathrm{CO}_{2}$ free nitrogen gas during these experiments resulted in a 1/e time of $0.9 \mathrm{~s}$.

The challenge then becomes to clearly distinguish between sampled emission exhaust and background concentrations, as well as to distinguish and discount emissions from other non-targeted vehicles. The identification of emission plumes from the data is accomplished by analyzing the multiple, synchronized, instruments on board the mobile laboratory. In addition to the pollutant sensors, these include 1) the readings from the sonic anemometer that allow consideration of the direction and speed of the incoming wind at the sampling port, 2) the images obtained with the video camera for observing the targeted vehicle, and 3) the real-time data log notes written by the researchers on-board the mobile laboratory. The use of these tools together with the analyses of the measured species signals are used to elucidate the presence of background air and emissions related to the targeted vehicle. Similarly, the emissions from the mobile laboratory (vehicle exhaust plus generator exhaust) itself were flagged out in our database using the same discriminants described above, plus the fact that the generator emitted characteris- tic high levels of methanol. As described in Fig. 1, the signals are correlated as long as they are part of the combustion products. When chasing a target vehicle, the instruments on board measure background and in-plume pollutant concentrations and their correlation is obtained using $\mathrm{CO}_{2}$ as the combustion plume tracer. This technique is made possible by the high time resolution and sensitivity of the instrumentation that is capable of capturing and quantifying the rapidly changing emission concentrations.

In our analysis, we considered a chase event useful when the duration of the chase was at least $5 \mathrm{~min}$, in order to characterize the emissions with a sufficient number of plume intercept measurements. After quality assurance procedures, a dataset of about $110 \mathrm{~h}$ containing valid 1-s data points for various species was obtained covering a wide area of the city. A total of 345 events with valid emission ratios were obtained with the procedure described above. Table 2 specifies the sample size and types of vehicles measured during the experiment. We estimated fleet average emission ratios 
Table 2. Chase and fleet average vehicle emissions experiments.

\begin{tabular}{|c|c|c|c|}
\hline $\begin{array}{l}\text { Event or chase } \\
\text { type }\end{array}$ & Sample size & MCMA fleet size & Description \\
\hline LDV & 119 & 2700000 & Fleet averaged emissions of Light Duty Vehicles ${ }^{a}$ \\
\hline HDT & 61 & 75000 & Heavy Duty Trucks (e.g. heavy trucks, tractor trailers) \\
\hline COL & 71 & 32000 & Colectivos $\mathrm{b}$ \\
\hline URB & 37 & 30000 & Urban buses ${ }^{b}$ \\
\hline CHR & 34 & 22000 & Inter-city buses or charters \\
\hline Others $^{\mathrm{d}}$ & 23 & 620000 & Includes combis, motorcycles, pickups, and non LDV vehicles $\leq 3$ tons \\
\hline
\end{tabular}

a Includes events classified as SAG, "Stop and Go" (sampling size 12), TRA “Traffic state" (sampling size 19), and CRU, "cruising at high speed" (sampling size 21), see text for details.

${ }^{\mathrm{b}}$ Colectivos are medium-size very popular public transport vehicles in the MCMA (for transporting about 25 people) powered by gasoline fuel. Colectivos powered by CNG or LPG are denominated here as COLg (sampling size 26). Urban buses are intra-city diesel buses. See text for details.

${ }^{c}$ Rounded values from the 2002 MCMA Emissions Inventory (SMA, 2004). Number of charters obtained from "Pasaje del Sevicio Publico Federal de Autotransporte" in GDF (2000).

d For our measurements, "Others" mean isolated emission plumes, fixed sampling or in specific places.

for light duty vehicles using the sampling periods when the mobile lab was surrounded by light duty gasoline vehicles under three different traffic conditions. We considered "Stop and Go" (SAG) situations when the mobile lab was in very heavy traffic conditions, with vehicle speeds lower than 16 $( \pm 8) \mathrm{km} / \mathrm{h}$ for $5 \mathrm{~min}$ or more. TRA events represent heavy traffic conditions with prevailing moderate speed, less than $40( \pm 16) \mathrm{km} / \mathrm{h}$, for 5 or more minutes, this is the most prevalent traffic mode in the MCMA. Finally, CRU conditions represent sampling periods with prevailing cruising at moderate and high speed in the city, higher than $56 \mathrm{~km} / \mathrm{h}$, for $5 \mathrm{~min}$ or more. These traffic conditions accounted for 52 classified fleet averaged traffic mode events. As shown in Table 2, 67 other measurements of light duty gasoline vehicle emissions were considered but they were not classified within these categories. In those cases, the classification was not possible either because the vehicle speed was not within a given vehicle speed category for more than 5 min (changing from one category to another, producing a combination of emission traffic modes) or because there was a strong influence from the emissions of an individual vehicle nearby (therefore biasing the fleet averaged sample).

Similar to the procedure used by Stedman et al. (1997), on the basis of the central limit theorem, the averaged emission ratios obtained should be approximately normally distributed if the samples were unbiased and sufficiently large. Therefore, the estimation of fleet average emission ratios with this method relies on the collection of average values representing large, unbiased samples of fleet emission measurements of light duty vehicles surrounding the mobile lab. Heavy duty trucks and the other public transport vehicles that were individually sampled, as reported in Table 2 , are intrinsically easier to measure with the chasing technique due to the strength of their emission signal and to the ease of following them
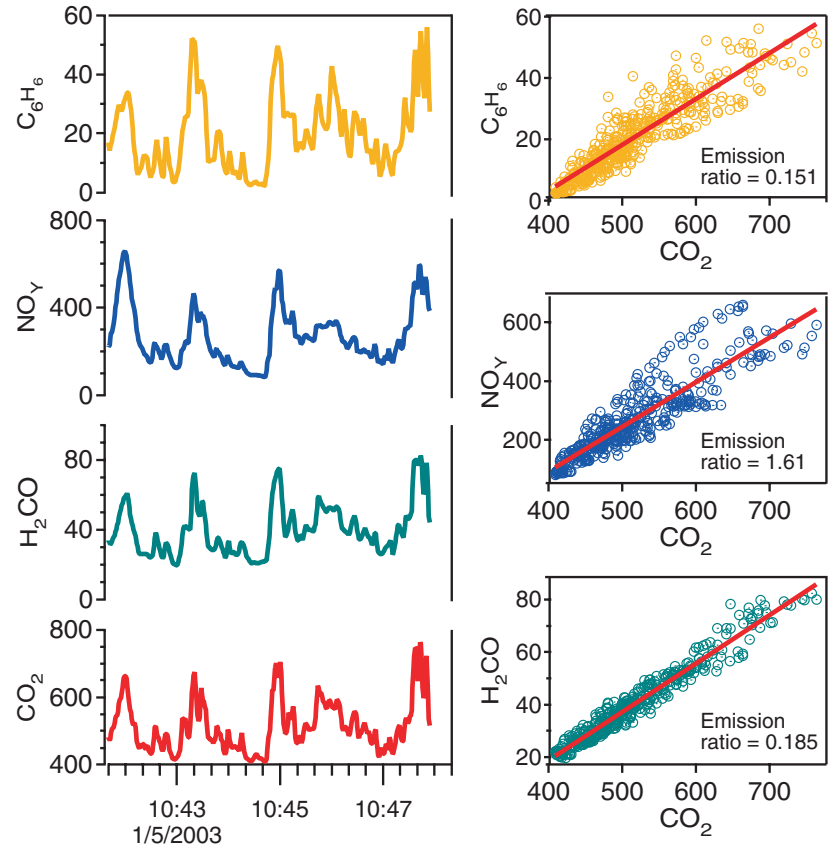

Fig. 1. Time series of benzene, $\mathrm{H}_{2} \mathrm{CO}$, and $\mathrm{NO}_{\mathrm{y}}$ in ppb units showing correlation with $\mathrm{CO}_{2}$ in ppm units. Estimated emission ratios in right-hand panels are in $\mathrm{ppb} / \mathrm{ppm}$ units.

while driving (Herndon et al., 2005a). The mobile laboratory also obtained information from other two types of events: 1) stationary periods when the mobile laboratory was located along a busy road or near a specific emission source, and 2) well-identified individual exhaust plumes for target vehicles but for shorter periods of time (less than $5 \mathrm{~min}$ ). We do not include the analysis of such periods here. 


\subsection{Data processing procedure}

The procedure for processing the data is described in the following paragraphs. Consider the general case of a target vehicle whose concentration at the emission exhaust location is given by $C_{i}^{e}$ for a given species $i$ while $C_{i}^{a}$ represents the ambient or background concentration for the same species $i$. In this way, the vehicle's emission and background concentrations for $\mathrm{CO}_{2}$ would be given by $C_{\mathrm{CO} 2}^{e}$ and $C_{\mathrm{CO} 2}^{a}$, respectively. Let the dilution $f$ be defined as the volume fraction of the exhaust plume for a given sampled volume in the measurement period $(\sim 1 \mathrm{~s})$. If the superscript $m$ refers to the measured concentration:

$f=\frac{C_{i}^{m}-C_{i}^{a}}{C_{i}^{e}-C_{i}^{a}}$.

We can solve for $C_{i}^{m}$ as:

$C_{i}^{m}=(1-f) C_{i}^{a}+f C_{i}^{e}$.

If $f=1$, this implies that a pure exhaust is being measured and when $f=0$, strictly ambient levels are being sampled. Now we make use of the equal dilution assumption for the species $i$ and for our tracer species $\mathrm{CO}_{2}$, from Eq. (1):

$\frac{C_{i}^{m}-C_{i}^{a}}{C_{i}^{e}-C_{i}^{a}}=\frac{C_{\mathrm{CO} 2}^{m}-C_{\mathrm{CO} 2}^{a}}{C_{\mathrm{CO} 2}^{e}-C_{\mathrm{CO} 2}^{a}}$

We are interested measuring the emission ratio for the species $i$ defined in this context as:

$E R_{i}=\frac{C_{i}^{e}}{C_{\mathrm{CO} 2}^{e}}$.

We can obtain this quantity from Eq. (3) after a series of simplifications. For example, with a typical concentration of $\mathrm{CO}_{2}$ in an engine exit plume in excess of $2 \%$ and ambient levels generally below $400 \mathrm{ppm}$, the following approximation is good to better than $2 \%$.

$C_{\mathrm{CO} 2}^{e}-C_{\mathrm{CO} 2}^{a} \cong C_{\mathrm{CO} 2}^{e}$.

Similarly, for other species it is common to observe $C_{i}^{a} / C_{i}^{e}$ values smaller than 0.05 . Equation (4) simplifies to the intuitive expression,

$E R_{i}=\frac{C_{i}^{e}}{C_{\mathrm{CO} 2}^{e}} \cong \frac{C_{i}^{m}-C_{i}^{a}}{C_{\mathrm{CO} 2}^{m}-C_{\mathrm{CO} 2}^{a}}$.

If the concentration $C_{i}^{m}$ is plotted against $C_{\mathrm{CO} 2}^{m}$ a very simple diagnostic arises, which resembles a locus of points around the ambient concentrations of $i$ and $\mathrm{CO}_{2}$ with rays extending toward higher concentrations of $\mathrm{CO}_{2}$ when a plume is sampled. The slope of the correlation plot is indicative of the Emission Ratio for species $i$ under the conditions in which the partially sampled plume was emitted.

\section{Results}

The measured emission ratios for the event types described above are shown in Table 3. Except for the fleet averaged light duty gasoline vehicles (SAG, TRA and CRU), the reported emission ratios correspond to the averaged values of the emissions from individual vehicle classes. Since the basis of the analytical procedure uses the covariance of the emitted species concentration to the emitted $\mathrm{CO}_{2}$ concentration under an equal dilution assumption, and therefore avoiding having to resolve the highly transient plume dilution behavior, we have excluded emission ratios for species measured with the relatively lower sampling frequency instruments described in Table 1. In that way, we avoid the uncertainties resulting from correlating a low frequency signal with high frequency signals. An alternative approach to estimating fleet average emissions of pollutants measured with the slower response instrument instruments on-board the Aerodyne Mobile Laboratory during MCMA-2003, is presented by Jiang et al. (2005).

The video camera images were used during the analysis process to discriminate target vehicle plumes from other potential sources. During the chasing experiments, the target vehicle's license plate was recorded so registration data could be accessed for additional information. The number of vehicles for which valid history information was available was too small to further classify the results by vehicle age and model.

Due to their large size, high exhaust volume, and relatively slow average speeds, public transport vehicles were sampled through individual chase events and were classified in this work as "colectivos" (COL), urban buses (URB), and charter buses (CHA). Colectivos are medium-size buses, with capacity for transporting about 25 people, and are very popular and intensively used throughout the MCMA. Colectivos are mainly gasoline-powered, although a small but growing fraction of them $(\sim 5 \%)$ are powered by CNG or LPG (CAM, 2004). By choosing a route used by colectivos fueled with CNG, we were able to sample 26 of this colectivo sub-class, classifying them as COLg. The URB category refers to intracity urban buses with capacity for transporting about 50 people; these buses were randomly selected as the mobile lab encountered them during on-road operations and a variety of transportation routes (and bus companies) were sampled. Charter buses, inter-city buses with a larger transport capacity than colectivos or urban buses, were sampled near the major bus terminal in the city. Here, the mobile lab chased the charter buses on a looped circuit as they were entering or leaving the facility. Sampled heavy-duty trucks (HDT) refer to large trucks such as tractor trailers, food supply and construction vehicles.

Ratios of emitted species reported in Table 3, such as aromatic VOCs/ $/ \mathrm{NO}_{\mathrm{y}}$ and $\mathrm{H}_{2} \mathrm{CO} / \mathrm{CH}_{3} \mathrm{CHO}$, for each vehicle or fleet type classification were obtained from the ratios of one-second measurements primary data as opposed to using 
Table 3. Measured emission ratios in [ppb/ppm] during the MCMA-2003 field campaign.

\begin{tabular}{|c|c|c|c|c|c|c|c|c|c|}
\hline \multirow[b]{2}{*}{ Pollutant } & \multicolumn{2}{|c|}{ Medium vehicles } & \multicolumn{4}{|c|}{ Light duty vehicles } & \multicolumn{3}{|c|}{ Heavy duty vehicles } \\
\hline & $\begin{array}{l}\mathrm{COL}^{\mathrm{d}} \\
(\mathrm{SD})^{\mathrm{c}}\end{array}$ & $\begin{array}{l}\mathrm{COLg} \\
\text { (SD) }\end{array}$ & $\begin{array}{l}\text { LDV } \\
\text { (SD) }\end{array}$ & $\begin{array}{l}\text { SAG } \\
\text { (SD) }\end{array}$ & $\begin{array}{l}\text { TRA } \\
\text { (SD) }\end{array}$ & $\begin{array}{l}\text { CRU } \\
\text { (SD) }\end{array}$ & $\begin{array}{l}\text { URB } \\
\text { (SD) }\end{array}$ & $\begin{array}{l}\text { CHR } \\
\text { (SD) }\end{array}$ & $\begin{array}{l}\text { HDT } \\
\text { (SD) }\end{array}$ \\
\hline NO & $\begin{array}{l}7.8 \\
(3.0)\end{array}$ & $\begin{array}{l}10.6 \\
(4.1)\end{array}$ & $\begin{array}{l}4.7 \\
(2.4)\end{array}$ & $\begin{array}{l}3.2 \\
(1.0)\end{array}$ & $\begin{array}{l}5.1 \\
(2.0)\end{array}$ & $\begin{array}{l}5.1 \\
(1.6)\end{array}$ & $\begin{array}{l}6.0 \\
(1.5)\end{array}$ & $\begin{array}{l}6.5 \\
(1.9)\end{array}$ & $\begin{array}{l}7.2 \\
(3.0)\end{array}$ \\
\hline $\mathrm{NO}_{2}$ & $\begin{array}{l}0.62 \\
(0.4)\end{array}$ & $\begin{array}{l}0.66 \\
(0.32)\end{array}$ & $\begin{array}{l}0.53 \\
(0.45)\end{array}$ & $\begin{array}{l}0.45 \\
(0.42)\end{array}$ & $\begin{array}{l}0.43 \\
(0.33)\end{array}$ & $\begin{array}{l}0.71 \\
(0.30)\end{array}$ & $\begin{array}{l}0.60 \\
(0.26)\end{array}$ & $\begin{array}{l}0.78 \\
(0.33)\end{array}$ & $\begin{array}{l}0.70 \\
(0.35)\end{array}$ \\
\hline NO & $\begin{array}{l}6.88 \\
(3.4)\end{array}$ & $\begin{array}{l}9.40 \\
(3.8)\end{array}$ & $\begin{array}{l}4.14 \\
(2.4)\end{array}$ & $\begin{array}{l}2.92 \\
(0.9)\end{array}$ & $\begin{array}{l}4.58 \\
(2.2)\end{array}$ & $\begin{array}{l}4.33 \\
(1.7)\end{array}$ & $\begin{array}{l}5.33 \\
(1.6)\end{array}$ & $\begin{array}{l}6.22 \\
(1.9)\end{array}$ & $\begin{array}{l}6.67 \\
(3.2)\end{array}$ \\
\hline $\mathrm{H}_{2} \mathrm{CO}$ & $\begin{array}{l}0.33 \\
(0.12)\end{array}$ & $\begin{array}{l}0.34 \\
(0.13)\end{array}$ & $\begin{array}{l}0.25 \\
(0.11)\end{array}$ & $\begin{array}{l}0.23 \\
(0.06)\end{array}$ & $\begin{array}{l}0.23 \\
(0.07)\end{array}$ & $\begin{array}{l}0.20 \\
(0.07)\end{array}$ & $\begin{array}{l}0.11 \\
(0.07)\end{array}$ & $\begin{array}{l}0.07 \\
(0.05)\end{array}$ & $\begin{array}{l}0.12 \\
(0.08)\end{array}$ \\
\hline $\mathrm{CH}_{3} \mathrm{CO}$ & $\begin{array}{l}0.04 \\
(0.02)\end{array}$ & $\begin{array}{l}0.06 \\
(0.01)\end{array}$ & $\begin{array}{l}0.04 \\
(0.02)\end{array}$ & $\begin{array}{l}0.04 \\
(0.02)\end{array}$ & $\begin{array}{l}0.04 \\
(0.02)\end{array}$ & $\begin{array}{l}0.04 \\
(0.01)\end{array}$ & $\begin{array}{l}0.02 \\
(0.02)\end{array}$ & $\begin{array}{l}0.02 \\
(0.02)\end{array}$ & $\begin{array}{l}0.03 \\
(0.02)\end{array}$ \\
\hline $\mathrm{H}_{2} \mathrm{CO} / \mathrm{CH}_{3} \mathrm{CHO}^{\mathrm{a}}$ & $\begin{array}{l}8.1 \\
(2.3)\end{array}$ & $\begin{array}{l}6.4 \\
(1.1)\end{array}$ & $\begin{array}{l}6.7 \\
(2.9)\end{array}$ & $\begin{array}{l}6.2 \\
(1.3)\end{array}$ & $\begin{array}{l}6.2 \\
(2.0)\end{array}$ & $\begin{array}{l}6.4 \\
(1.8)\end{array}$ & $\begin{array}{l}7.2 \\
(2.4)\end{array}$ & $\begin{array}{l}4.9 \\
(3.2)\end{array}$ & $\begin{array}{l}5.1 \\
(2.3)\end{array}$ \\
\hline Benzene & $\begin{array}{l}0.08 \\
(0.04)\end{array}$ & $\begin{array}{l}0.03 \\
(0.01)\end{array}$ & $\begin{array}{l}0.13 \\
(0.08)\end{array}$ & $\begin{array}{l}0.14 \\
(0.04)\end{array}$ & $\begin{array}{l}0.10 \\
(0.03)\end{array}$ & $\begin{array}{l}0.10 \\
(0.04)\end{array}$ & $\begin{array}{l}0.04 \\
(0.05)\end{array}$ & $\begin{array}{l}0.02 \\
(0.02)\end{array}$ & $\begin{array}{l}0.03 \\
(0.03)\end{array}$ \\
\hline Toluene & $\begin{array}{l}0.14 \\
(0.07)\end{array}$ & $\begin{array}{l}0.04 \\
(0.02)\end{array}$ & $\begin{array}{l}0.25 \\
(0.12)\end{array}$ & $\begin{array}{l}0.28 \\
(0.07)\end{array}$ & $\begin{array}{l}0.18 \\
(0.06)\end{array}$ & $\begin{array}{l}0.18 \\
(0.08)\end{array}$ & $\begin{array}{l}0.05 \\
(0.05)\end{array}$ & $\begin{array}{l}0.02 \\
(0.02)\end{array}$ & $\begin{array}{l}0.04 \\
(0.04)\end{array}$ \\
\hline C2-Benzene & $\begin{array}{l}0.19 \\
(0.09)\end{array}$ & $\begin{array}{l}0.05 \\
(0.04)\end{array}$ & $\begin{array}{l}0.32 \\
(0.16)\end{array}$ & $\begin{array}{l}0.32 \\
(0.11)\end{array}$ & $\begin{array}{l}0.22 \\
(0.09)\end{array}$ & $\begin{array}{l}0.19 \\
(0.09)\end{array}$ & $\begin{array}{l}0.06 \\
(0.06)\end{array}$ & $\begin{array}{l}0.03 \\
(0.04)\end{array}$ & $\begin{array}{l}0.05 \\
(0.05)\end{array}$ \\
\hline C3-Benzene & $\begin{array}{l}0.16 \\
(0.08)\end{array}$ & $\begin{array}{l}0.03 \\
(0.02)\end{array}$ & $\begin{array}{l}0.24 \\
(0.15)\end{array}$ & $\begin{array}{l}0.24 \\
(0.09)\end{array}$ & $\begin{array}{l}0.15 \\
(0.05)\end{array}$ & $\begin{array}{l}0.15 \\
(0.08)\end{array}$ & $\begin{array}{l}0.05 \\
(0.06)\end{array}$ & $\begin{array}{l}0.03 \\
(0.05)\end{array}$ & $\begin{array}{l}0.05 \\
(0.06)\end{array}$ \\
\hline$m / z .57^{\mathrm{e}}$ & $\begin{array}{l}0.26 \\
(0.21)\end{array}$ & $\begin{array}{l}0.03 \\
(0.07)\end{array}$ & $\begin{array}{l}0.38 \\
(0.23)\end{array}$ & $\begin{array}{l}0.39 \\
(0.10)\end{array}$ & $\begin{array}{l}0.29 \\
(0.12)\end{array}$ & $\begin{array}{l}0.28 \\
(0.10)\end{array}$ & $\begin{array}{l}0.09 \\
(0.07)\end{array}$ & $\begin{array}{l}0.04 \\
(0.04)\end{array}$ & $\begin{array}{l}0.09 \\
(0.08)\end{array}$ \\
\hline $\mathrm{NH}_{3}$ & $\mathrm{ND}^{c}$ & ND & $\begin{array}{l}0.12 \\
(0.07)\end{array}$ & $\begin{array}{l}0.09 \\
(0.05)\end{array}$ & $\begin{array}{l}0.09 \\
(0.06)\end{array}$ & $\begin{array}{l}0.11 \\
(0.07)\end{array}$ & $\begin{array}{l}0.04 \\
(0.03)\end{array}$ & ND & $\begin{array}{l}0.06 \\
(0.04)\end{array}$ \\
\hline Aromatics $/ \mathrm{NO}^{\mathrm{a}, \mathrm{b}}$ & $\begin{array}{l}0.09 \\
(0.08)\end{array}$ & $\begin{array}{l}0.02 \\
(0.01)\end{array}$ & $\begin{array}{l}0.30 \\
(0.27)\end{array}$ & $\begin{array}{l}0.31 \\
(0.10)\end{array}$ & $\begin{array}{l}0.14 \\
(0.07)\end{array}$ & $\begin{array}{l}0.11 \\
(0.05)\end{array}$ & $\begin{array}{l}0.03 \\
(0.03)\end{array}$ & $\begin{array}{l}0.02 \\
(0.02)\end{array}$ & $\begin{array}{l}0.03 \\
(0.03)\end{array}$ \\
\hline
\end{tabular}

a Obtained from individual emission ratios, see text for details, units in $\mathrm{ppb} / \mathrm{ppb}$.

${ }^{\mathrm{b}}$ For "aromatic VOCs" we considered the sum of Benzene, Toluene, C2-Benzene (sum of xylene isomers, ethylbenzene, and benzaldehyde) and $\mathrm{C} 3$-Benzene (sum of $\mathrm{C}_{9} \mathrm{H}_{12}$ isomers and $\mathrm{C}_{8} \mathrm{H}_{8} \mathrm{O}$ isomers).

${ }^{c} \mathrm{SD}$ : 1-standard deviation; ND: Non determined

${ }^{\mathrm{d}}$ See Table 2 and text for definition of vehicle chasses.

e $m / z, 57$ represents the sum of MTBE and butenes for gasoline vehicles. Neutral components have not been assigned to this mass for CNG and diesel vehicles.

averaged ratios. In Fig. 2 we present the frequency distributions of measured emission ratios for various species and ratios of emitted species. The frequency distributions were obtained using all valid emission measurements for all the sampled species and vehicle categories. Similarly, frequency distributions for ratios of emitted species were also obtained from the ratios of individual, one-second, measurements.

\section{Discussion}

An important aspect of the analysis of the data collected is to determine how representative it is of the vehicle fleet emissions in the MCMA. Given the large population of the vehicle fleet, the presence of various driving modes and the variability of all other parameters that play a role in the emission process in real world driving conditions, this is certainly an important issue to consider for any emission measurement technique. As shown in Table 2, the large size of the vehicle fleet in the MCMA for all vehicle categories predisposes a large sample size for any estimate attempt for a sample to be representative with traditional sampling techniques. Nevertheless, current estimations of emission factors for LDVs in the Emissions Inventory for the MCMA are based on a very small number of measurements performed in 1999 with laboratory-controlled conditions of individual vehicles (CAM, 2004). Furthermore, current estimates of emission factors for HDTs in the same inventory are entirely based on modeling estimates using a modified version of Mobile5, the U.S. Environmental Protection Agency's motor vehicle emission inventory model. 

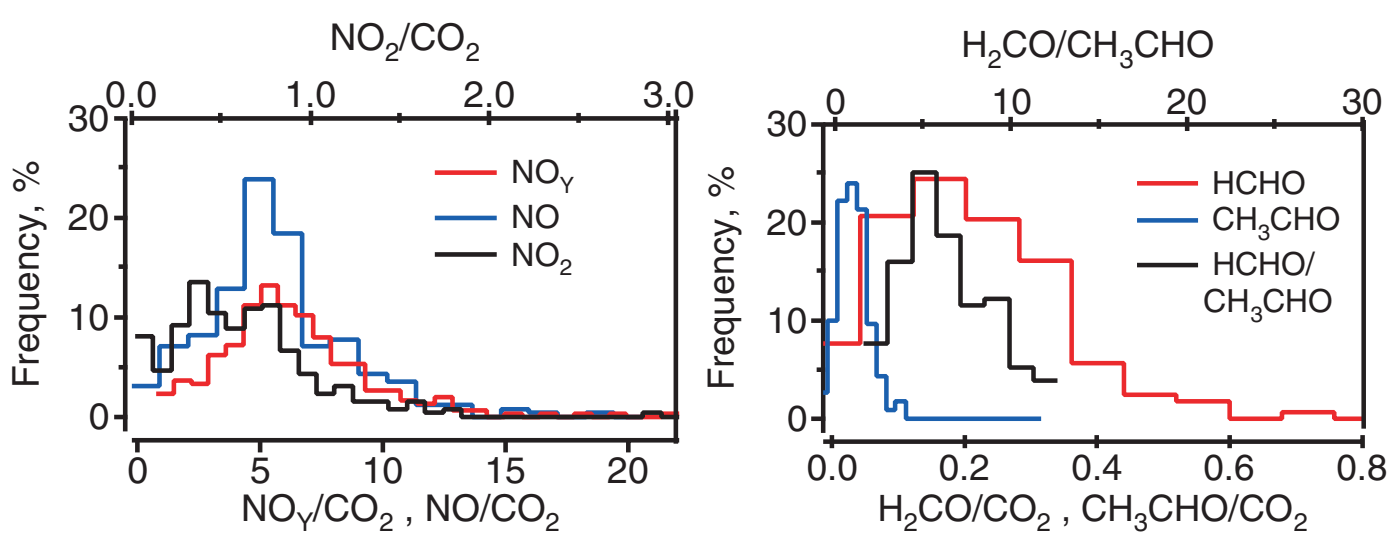

Benzene/Toluene
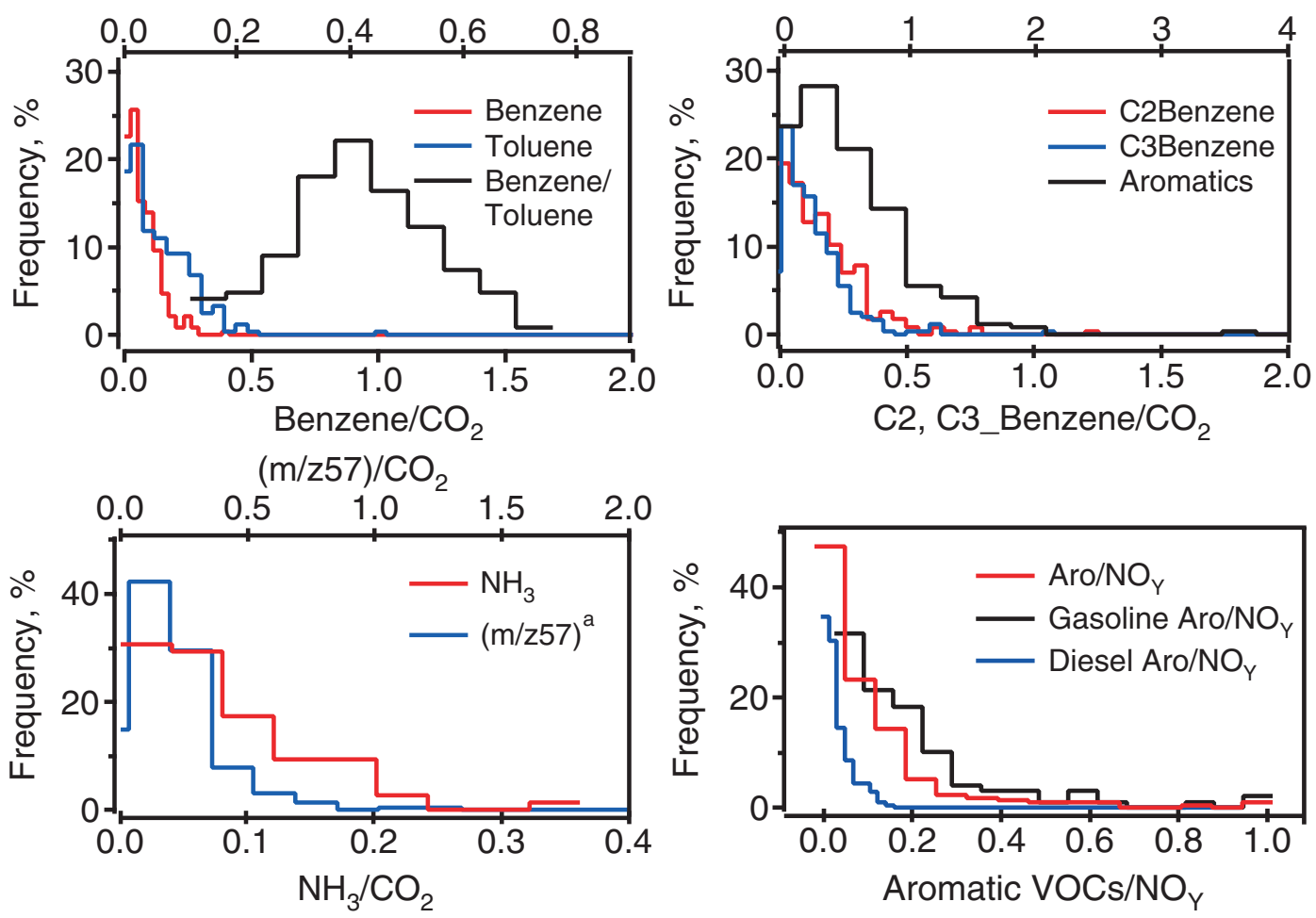

Fig. 2. Frequency distributions of measured emission ratios [ppb/ppm] during the MCMA.

a $(m / z 57) / \mathrm{CO}_{2}$ represents MTBE + butenes for gasoline vehicles.

In this work, we have extended the analysis procedure for the chase technique by considering measurements for both fleet averaged and individual in-class vehicle emissions. As described above, we estimated fleet LDV average emissions by analyzing the sampling periods when the mobile laboratory is measuring the mixed background air with the emissions of the surrounding vehicles for sustained periods of time. The assumption in this procedure is that the sampled emissions from a multitude of sources are sufficiently well mixed before arriving to the mobile lab sampling port. Since this condition is not totally controlled a priori for the experiment, it has to be determined from the analysis of the emis- sion signals, the anemometer readings and the video camera. We have further classified such periods by driving state as SAG, TRA and CRU with the velocity criteria previously described. On the basis of the central limit theorem, the obtained fleet averages for each driving state should also be approximately normally distributed if the samples are unbiased and sufficiently large. In such case, symmetric confidence intervals around the average could be established for fleet emissions estimates.

The variability in the emission estimates can be observed in the form of standard deviations reported in Table 3. Except for $\mathrm{NO}_{2}$, the results for fleet vehicle estimates show standard 
deviations that are significantly smaller than the observed averaged emission values. This is expected for fleet average estimates using the central limit theorem. $\mathrm{NO}_{2}$ is a difficult species to measure with this technique due to its high reactivity and to potential ambient production via the reaction of NO with oxidizing species, such as ozone, that can be significant in a highly polluted atmosphere. In some cases, the sum of the $\mathrm{NO}$ and $\mathrm{NO}_{2}$ emission ratios is greater than the $\mathrm{NO}_{\mathrm{y}}$ emission ratio. Although this is not physically possible for an individual vehicle, it may occur for the average values of groups of vehicles.

Due to the relatively small sample size and the lack of vehicle model year information, in the case of the individual chase mode emission measurements of HDT and public transport vehicles the observed variability may not represent the true variability of the population of emissions for these vehicle categories. The larger observed variability in these cases is likely the result of the large range of vehicles models, the variety of engine, fuel delivery, and emission control technologies, distribution of vehicle age and maintenance quality, and the variability of other parameters affecting emissions in real world driving conditions. As such, the averages and confidence intervals for these categories may not be representative of the entire fleet. Unless there is a significant increase of the sampling size, however, at this point the question of how much the obtained frequency distributions would change by increasing the sampling size is unsolved.

In order to further reduce any systematic bias in the measured emission ratios from individual chasing events reported in Table 3, during the experiment we intentionally did not follow a given vehicle class on the basis of the visible strength and blackness of its exhaust. That procedure helped to avoid over sampling of high emitting vehicles in the sampling population. Similarly, since the mobile laboratory followed different driving routes each day during the campaign throughout the city, the sampled emissions are most likely not biased by spatial differences in vehicle populations.

The obtained emission frequency distributions shown in Fig. 2 provide us with some interesting insights into the mobile emission characteristics in the MCMA. Different from a smoothed distribution, a pronounced cityscape type of graph may indicate the need for a larger sampling size population in our measurements. This is especially evident in the $\mathrm{NH}_{3}$ emission distribution, which was constructed from about $25 \%$ of the sample size for the other species. The smaller sample size for $\mathrm{NH}_{3}$ was due to the need to divert a LiCOR $\mathrm{CO}_{2}$ instrument periodically to a shorter sampling inlet designed to avoid surface losses of $\mathrm{NH}_{3}$ as well as some instrumental problems characteristic of a first field deployment. Nevertheless, to our knowledge, this represents the first field deployment of a quantum cascade TILDAS on-board any mobile laboratory.

We define aromatic VOCs as the sum of benzene, toluene, C2-benzene (sum of xylene isomers, ethylbenzene, and ben- zaldehyde) and $\mathrm{C} 3$-benzene (sum of $\mathrm{C}_{9} \mathrm{H}_{12}$ isomers and $\mathrm{C}_{8} \mathrm{H}_{8} \mathrm{O}$ isomers) as described in Rogers et al. (2006). Figure 2 shows that these aromatic $\mathrm{VOC} / \mathrm{CO}_{2}$ emission ratios tend to have higher frequency around a mean value but are also severely skewed towards high values of emission ratios. Although this behavior is often seen with VOC emission distributions, we observe that the reported distributions of the ratios benzene/toluene and $\mathrm{H}_{2} \mathrm{CO} / \mathrm{CH}_{3} \mathrm{CHO}$ tend to be normally distributed, indicating the co-emission nature of these species in real world driving conditions.

The measured aromatic $\mathrm{VOCs} / \mathrm{NO}_{\mathrm{y}}$ ratio presented in Fig. 2 shows a highly skewed but smoothly continuous hyperbola type distribution. Since the detected aromatic VOC content of the emissions from the CNG colectivos are very low and close to the instrumental and analytical uncertainty, we have excluded them from the plotted aromatic species distributions. Therefore, an explanation for the behavior of the aromatic $\mathrm{VOCs} / \mathrm{NO}_{\mathrm{y}}$ distribution may rely on the emission characteristics of the vehicle fleet sampled (populations of vehicles with low versus high aromatic $\mathrm{VOCs} / \mathrm{NO}_{\mathrm{y}}$ emissions) and on the fact that the two major fuel types, gasoline and diesel, are included in the sample. To investigate which of these two aspects has a greater impact on the aromatic VOCs/ $/ \mathrm{NO}_{\mathrm{y}}$ distribution we included in Fig. 2 the corresponding frequency distributions of gasoline and diesel vehicles that were sampled. The comparison of these distributions reveals that within the gasoline vehicle fleet low and high emitting aromatic VOCs/ $\mathrm{NO}_{\mathrm{y}}$ vehicles can be distinguished. As long as the frequency distribution is representative of the aromatic $\mathrm{VOCs} / \mathrm{NO}_{\mathrm{y}}$ ratio in the vehicle fleet, this result has important implications for the design of air quality control strategies by allowing the possibility to direct air quality emission reduction strategies towards controlling the aromatic $\mathrm{VOCs} / \mathrm{NO}_{\mathrm{y}}$ ratio in different parts of the vehicle fleet and/or ranges of driving modes.

Public transport colectivos and buses are a very important part of the transport system in the MCMA (Gakenheimer et al., 2002). As an example, colectivos represent only about $1 \%$ of the vehicle fleet in the MCMA but, together with the other small popular public transport vehicle called "combis", they account for almost $60 \%$ of the trips per person per day (CAM, 2004). Results presented in Table 3 indicate that, on a mole per mole basis, colectivos showed the highest $\mathrm{NO}_{\mathrm{x}}$ emissions ratios among the sampled vehicles, especially for colectivos fueled with $\mathrm{CNG}$. The higher $\mathrm{NO}_{\mathrm{x}}$ emissions ratios for CNG colectivos is in accordance with their corresponding higher $\mathrm{CH}_{3} \mathrm{CHO} / \mathrm{H}_{2} \mathrm{CO}$ ratio as compared to gasoline fueled colectivos. The higher aldehyde emission ratios found in this work agree with dynamometer studies for $\mathrm{CNG}$ heavy duty vehicles performed by Huai et al. (2003) and Kado et al. (2005).

The quantification of high aldehyde emissions from MCMA vehicles may have important impacts on the photochemistry in urban areas (García et al., 2005) and the generally high emissions of aromatic and aldehyde air toxics 


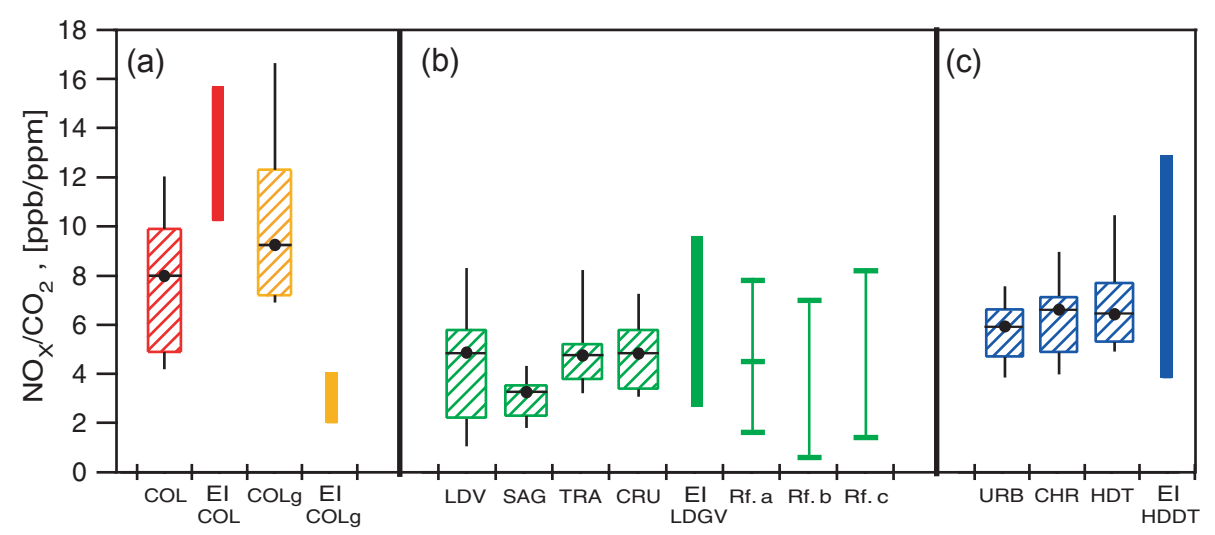

Fig. 3. Comparison of $\mathrm{NO}_{\mathrm{x}}$ emission factors obtained in this work (box plots) with estimates from the official $2002 \mathrm{MCMA}$ Emissions Inventory (EI) (solid bars) and other studies (light lines) for panels: (a) colectivo buses, (b) Ligth duty Gasoline Vehicle (LDGV), and (c) Heavy Duty Diesel Trucks (HDDT). Box plots represent the 10, 25, 75, and 90 percentiles along with the mean of our measurements. Filled bars represent the minimum and the maximum EI estimates for the corresponding vehicle category. Rf. a: Schifter et al. (2005); Rf. b: Schifter et al. (2004); Rf. c: Schifter et al. (2000).

a For this comparison, we used fuel densities of $0.75,0.85$ and $0.41 \mathrm{~kg} / \mathrm{l}$ for gasoline, diesel ad CNG fuels, respectively. Similarly, we considered 70.3, 72.5 and 62.5 moles of $\mathrm{C}$ per $\mathrm{kg}$ of fuel for gasoline, diesel ad CNG, respectively. Fuel economies were assumed as follows: $10,2.1$ and $1.6 \mathrm{~km} / \mathrm{l}$ for gasoline, diesel and CNG fleets, respectively.

may have important health implications. $\mathrm{H}_{2} \mathrm{CO} / \mathrm{CH}_{3} \mathrm{CHO}$ ratios showed a value of $6.2 \pm 1.8[\mathrm{ppb} / \mathrm{ppb}]$ averaged over all gasoline vehicle fleet emission measurements and the driving mode did not significantly affect this ratio. Measured emissions indicate that the emitted species that are most influenced by driving mode are $\mathrm{NO}_{\mathrm{x}}$, aromatic VOCs and their aromatic VOCs $/ \mathrm{NO}_{\mathrm{y}}$ ratio. That effect was only investigated in the fleet average gasoline vehicle fleet and not in the individual chase emission measurements. As such, the observed variability within individual vehicle categories may be due to internal variability of the specific power of the vehicles, vehicle age and model, and emission control technology, among others. Nevertheless, the observed variability within driving modes for averaged vehicle fleet emissions indicates that this type of analysis for ratios of selected VOC to $\mathrm{NO}_{\mathrm{x}}$ species should be considered during the design of air quality control strategies that are based on the modification of the driving patterns, or modes, within the city.

An important aspect of this work lies in the comparison of the obtained results with the estimates for emission factors used in the official emissions inventory as well as with other measurements performed in the MCMA and other cities. The emissions inventory in the MCMA has been revised or updated every two years since 1994 and with homogenous methodologies since 1998. For comparisons with our results, we use the 2002 official Emissions Inventory (EI) for the MCMA considering the categories of light duty vehicles, colectivos and heavy duty trucks for $\mathrm{NO}_{\mathrm{x}}$ emission factors. We present the comparison of our results with other estimations of emission factors in Fig. 3. The box plots represent the 10th percentile, 1st quartile, mean, 3rd quartile, and 90th percentile of our measurements for each category whereas the thinner adjacent colored bars represent the range of emission factors used in the emissions inventory. Light bars represent the estimations of emission factors using other techniques. In order to compare the obtained emission ratios in $\mathrm{ppb} / \mathrm{ppm}$ units with other measurements performed with different sampling techniques it is necessary to make use of fuel properties and stoichiometric combustion assumptions. Data considered for this purpose are presented in the notes for Fig. 3.

Figure 3 shows that $\mathrm{NO}_{\mathrm{x}}$ emissions factors used in the emissions inventory for light duty vehicles are within the range of our measurement results and that a similar range of values are obtained with other techniques for this category. Note however that in Fig. 3 the range for the emission factors used in the emissions inventory considers the minimum and the maximum values, which are related to newest and oldest vehicle model years, and does not represent vehicle fleet estimates. However, Schifter et al. (2005) represents values taken from the minimum and maximum averaged emission factors for light duty vehicles from a remote sensing study performed in 2000 in the MCMA. The other two references shown for comparison of LDV emission factors in Fig. 3, Schifter et al. (2004) and Schifter et al. (2000), represent laboratory dynamometer studies with prescribed driving cycles. Interestingly, the reported emission factors among the different techniques are similar. Nevertheless, the reported values are not weighted by the number of vehicles or any other activity parameter that may indicate their relative importance on the estimation of $\mathrm{NO}_{\mathrm{x}}$ emissions. 
Table 4. Comparison of emissions (in tons/year) estimated in this work with emissions estimated in other studies for the MCMA and other U.S. cities.

\begin{tabular}{|c|c|c|c|c|c|c|}
\hline & This work ${ }^{\mathrm{f}}$ & $2002 \mathrm{EI}^{\mathrm{a}}$ & Jiang et al. $(2005)^{\mathrm{d}}$ & $\begin{array}{l}\text { Schifter et } \\
\text { al. }(2000)^{b}\end{array}$ & $\begin{array}{l}\text { Schifter } \\
\text { al. }(2005)^{\mathrm{c}}\end{array}$ & Los Angeles ${ }^{\mathrm{e}}$ \\
\hline $\mathrm{NO}_{\mathrm{x}}$ & $100600 \pm 29200$ & 92500 & $120000 \pm 3000$ & ND & $100200 \pm 23500$ & 280000 \\
\hline Benzene & $4090 \pm 850$ & $\mathrm{ND}^{\mathrm{h}}$ & $3800 \pm 100$ & 1590 & ND & 2290 \\
\hline Toluene & $10100 \pm 2200$ & ND & ND & ND & ND & ND \\
\hline $\mathrm{H}_{2} \mathrm{CO}$ & $3020 \pm 720$ & ND & ND & 397 & ND & 1900 \\
\hline $\mathrm{CH}_{3} \mathrm{CHO}$ & $770 \pm 230$ & ND & ND & 167 & ND & 605 \\
\hline $\mathrm{NH}_{3}$ & $900 \pm 500$ & 3120 & ND & ND & ND & $8800-10600^{\mathrm{g}}$ \\
\hline
\end{tabular}

${ }^{a}$ Considers the emissions from the gasoline vehicle fleet: private vehicles, taxis, combis, colectivos and pickups.

b Based on a laboratory study of around 50 vehicles (ages from 1984 to 1999) tested under a FTP cycle.

${ }^{c}$ Based on a remote sensing study in 2000 for the MCMA.

$\mathrm{d}$ Considers the total vehicle fleet, LDVs and HDVs.

e Total on-road gasoline mobile emissions estimates for 2004 in the South Coast Air Basin. Source: CARB, 2005.

${ }^{\mathrm{f}}$ Uses gasoline fuel consumption by the transport sector alone estimated for 2002 in the MCMA Emissions Inventory and the fuel properties reported in Fig. 3 of this document.

g Data includes all $\mathrm{NH}_{3}$ on-road mobile emissions taken from Fraser and Cass, 1998.

${ }^{\mathrm{h}}$ ND: A value Non Determined in the study.

A similar comparison of our results with the $\mathrm{NO}_{\mathrm{x}}$ emission factors used in the MCMA emissions inventory for public transport vehicles indicates a possible overestimation in the gasoline-powered colectivos category. Similarly, our results indicate a possibly severe underestimation of $\mathrm{NO}_{\mathrm{x}}$ emission factors for CNG-powered colectivos. The emissions inventory uses the same $\mathrm{NO}_{\mathrm{x}}$ emission factors for our classified vehicle categories of URB, CHR and HDT, and their range falls within our results. However, in contrast to the comparison with the light duty vehicle fleet, these results correspond to individual vehicle measurements and therefore the observed variability may or may not be representative of a given vehicle category. Note, however, that in the case of the CNG colectivos, the range estimated in the emissions inventory is too small compared to the range of the observed variability. Therefore, assuming that the observed variability is real, this may be indicative of a real underestimation of $\mathrm{NO}_{\mathrm{x}}$ emission factors used in the emissions inventory for this category.

The analysis of a possible under/over estimation of emission factors is only a part of the validation of an emissions inventory. Since the emissions inventory is based on assumed values for activity parameters (e.g. distances traveled) that may introduce further uncertainty in the estimation of mobile emissions, the final estimation of emissions is not trivial. A possible way to circumvent this difficulty is to consider the use of fuel based emission factors together with estimates of fuel consumption in a given region (Singer and Harley, 2000). We have followed this approach transforming our measured emission ratios to units of grams per unit of fuel consumed using the previously described assumptions of fuel properties and vehicle fuel efficiency. In the transforma- tion of the emission factors we only considered the gasoline vehicle fleet averaged estimates.

Table 4 shows the comparison of our emission estimates for the MCMA with other studies. The results indicate that $\mathrm{NO}_{\mathrm{x}}$ emissions estimated for LDVs in the emissions inventory are within the range estimated using the fuel based emission factors in this work of $100600 \pm 29200$ metric tons per year. The upper and lower limits correspond to 1 standard deviation obtained from the observed emission factor for the LDV category. Although Table 4 shows that the comparisons for the total $\mathrm{NO}_{\mathrm{x}}$ emissions for light duty vehicles between the emission inventory and this work may be within the confidence intervals, the possible under/over estimation of emission factors for individual vehicles ages and models may still be present in the emissions inventory. The application of the chase technique for systematically comparing emission factors by vehicle age and model would then be desirable to address this question.

Our results indicate larger emission estimates for benzene, toluene, formaldehyde and acetaldehyde than Schifter et al. (2000), which was based on a limited sample of vehicles tested in controlled laboratory conditions. The emissions inventory does not provide estimates of speciated hydrocarbon emissions and therefore, no comparison is possible for these species. In Table 4 we also show the comparison of estimated toxic VOC emissions between Los Angeles and the MCMA. The results indicate that the annual estimates of benzene, acetaldehyde and formaldehyde LDV emissions in the MCMA are similar or higher than the corresponding estimated toxic VOC emissions in Los Angeles. For the year of comparison (2003), the vehicle fleet in the Los Angeles area was 3.2 times higher than the entire fleet in the MCMA and the 
annual gasoline consumption was 3.3 times higher (Molina et al., 2004). Besides the larger size of the vehicle fleet and the corresponding higher fuel consumption in the Los Angeles area, two other important aspects of the comparison are the older vehicle fleet composition and the smaller fraction of vehicles with emission control technologies in the MCMA. For example, only about $30 \%$ of the vehicle fleet count with Tier ( 0 and 1$)$ control emission technologies in the MCMA as compared to $91 \%$ in Los Angeles (Molina and Molina, 2002). This indicates that an aged vehicle fleet and a smaller fraction of vehicles with efficient emission control technologies may have a significant impact on the overall burden of toxic VOC emissions in the MCMA. Bishop et al. (2001) has reported a slight but statistically significant increase of NO with increased altitude for heavy duty trucks. Nevertheless, reasons for the altitude relationship are unclear and may be subject to particular characteristics and composition of the sampled vehicle fleet.

As noted above, the sampling size of the measured onroad $\mathrm{NH}_{3}$ emissions was significantly smaller than the rest of the reported species due to the lack of a dedicated fast response $\mathrm{CO}_{2}$ monitor on the short, fast flow inlet necessary for $\mathrm{NH}_{3}$ measurements and some QC-TILDAS instrument problems characteristic of a first field deployment. As such, the $\mathrm{NH}_{3}$ emission estimate in Table 4 has large confidence intervals and may not be fully representative of the LDV vehicle fleet. Nevertheless, the entire range estimate is significantly smaller than the vehicle $\mathrm{NH}_{3}$ emissions estimated in the current model based emissions inventory for the MCMA and than the on-road $\mathrm{NH}_{3}$ emission estimate in Los Angeles. Given the median age of the MCMA vehicle fleet, this is not surprising since $\mathrm{NH}_{3}$ emissions are dominated by newer gasoline powered vehicles equipped with $\mathrm{NO}_{\mathrm{x}}$ reduction catalysts. In our measurements, $\mathrm{NH}_{3}$ emissions for MCMA LDVs seem to be much higher for newer vehicles, which are presumably equipped with reduction catalysts for $\mathrm{NO}_{\mathrm{x}}$ and appear to be relatively independent of driving state. $\mathrm{NH}_{3}$ emitted from on-road vehicles may react rapidly with acid vapors to form high burdens of secondary particulate matter near heavily traveled roadways, impacting fine particle exposure levels for travelers and near by residents. The level of $\mathrm{NH}_{3}$ emissions from newer LDV vehicles in the MCMA do appear to be significantly higher than the emissions of similar vehicles in the U.S. (Herndon et al., 2005b). The impact of vehicular $\mathrm{NH}_{3}$ emissions on the MCMA $\mathrm{NH}_{3}$ emission inventory will be addressed more thoroughly in a separate publication (Shorter et al., 2006 ${ }^{1}$ ).

\footnotetext{
${ }^{1}$ Shorter, J. H., Herndon, S. C., Zahniser, M. S., et al.: Atmospheric Ammonia in Mexico City during MCMA-2003, Atmos. Chem. Phys. Discuss., to be submitted, 2006.
}

\section{Conclusions}

In this work, we have extended the analysis procedure for the on-road mobile laboratory measurements by considering measurements of both fleet averaged emission measurements and individual vehicle emissions. The measured emission ratios represent a sample of emissions of in-use vehicles under real world driving conditions for the MCMA. From the relative amounts of $\mathrm{NO}_{\mathrm{x}}$ and selected VOC's sampled, the results indicate that the technique is capable of differentiating among vehicle categories and fuel type in real world driving conditions. We have further classified our results by vehicle categories and driving mode using pre-established velocity criteria in our analysis. Our measurements of emission ratios for both CNG and gasoline powered "colectivos" indicate that - in a mole per mole basis - have significantly larger $\mathrm{NO}_{\mathrm{x}}$ and aldehydes emissions ratios as compared to other sampled vehicles in the MCMA. Similarly, ratios of selected VOCs and $\mathrm{NO}_{\mathrm{y}}$ showed a strong dependence on traffic mode. The potential implications of these results are important for the design of air quality control strategies based on the modification of the driving modes and the retrofitting of public transport vehicles.

By using a fuel consumption based approach together with the measured emission factors in this work, we estimate $\mathrm{NO}_{\mathrm{x}}$ emissions as $100600 \pm 29200$ metric tons per year for LDGVs in the MCMA for 2003. According to these results, annual $\mathrm{NO}_{\mathrm{x}}$ emissions estimated in the emissions inventory for this category are within the range of our estimated $\mathrm{NO}_{\mathrm{x}}$ annual emissions. However, we did not explore the classification of emissions by vehicle age and under/over estimations of $\mathrm{NO}_{\mathrm{x}}$ emissions for individual vehicle age categories can still exist in the emissions inventory. We also have estimated annual emissions for benzene, toluene, formaldehyde and acetaldehyde in the MCMA for the first time following a fuel-based procedure. The results indicate that the annual estimates of benzene, acetaldehyde and formaldehyde LDV emissions in the MCMA may be greater than previously reported and that their magnitudes are similar or higher than the corresponding estimated toxic VOC emissions in Los Angeles and other U.S. cities. Vehicle age fleet composition and the relatively small fraction of vehicles with emission control technologies in the MCMA may significantly contribute for these large toxic emissions. Finally, ammonia emitted from newer reductive catalyst equipped LDVs may react rapidly with air vapors to form high burdens of secondary particulate matter near heavily traveled roadways.

Acknowledgements. The authors gratefully acknowledge the Mexican Metropolitan Environmental Commission, the U.S. National Science Foundation (ATM-0308748 and ATM-0528227) and the Department of Energy (Award DE-FG02-05ER63980 and DE-FG02-05ER3982) for financial support. Funding for the PTRMS instrument was provided by the National Science Foundation Major Research Instrumentation Program, Murdock Charitable Trust and Montana State University. M. Zavala is a Molina Fellow 
at MIT. We thank J. Sarmiento for providing the emissions inventory data and to $\mathrm{N}$. Rodríguez for the gasoline sales information.

Edited by: U. Pöschl

\section{References}

GDF (Gobierno del Distrito Federal): Agenda estadistica del distrito federal-Transporte, Gobierno de México, México, available at http://www.df.gob.mx/agenda2000/, 2000.

Barnard, J. C., Kassianov, E. I., Ackerman, T. P., Frey, S., Johnson, K., Zuberi, B., Molina, L. T., Molina, M. J., Gaffney, J. S., and Marley, N. A.: Measurements of black carbon specific absorption in the Mexico City Metropolitan Area during the MCMA 2003 field campaign, Atmos. Chem. Phys. Discuss., 5, 40834113, 2005, http://www.atmos-chem-phys-discuss.net/5/4083/2005/.

Bishop, G. A., Starkey, J. R., Ihlenfeldt, A., Williams, W. J., and Stedman, D. H.: IR long-path photometry: a remote sensing tool for automotive emissions, Analytical Chemistry, 61(10), 671677, 1989.

Bishop, G. A., Morris, J. A., Stedman, D. H., Cohen, L. H., Countess, R. J., Countess, S. J., Maly, P., and Scherer, S.: The effects of altitude on Heavy-Duty Diesel Truck on-road emissions, Environ. Sci. Technol., 35, 1574-1578, 2001.

Cadle, S. H., Gorse, R. A., Bailey, B. K., and Lawson, D. R.: Realworld vehicle emissions: a summary of the Eleventh Coordinating Research Council On-Road Vehicle Emissions Workshop, J. Air Waste Manage. Assoc., 52(2), 220-236, 2002.

Canagaratna, M., Jayne, J., Ghertner, D., Herndon, S., Shi, Q., Jimenez, J., Silva, P., Williams, P., Lanni, T., Drewnick, F., Demerjian, K., Kolb, C., and Worsnop, D.: Chase studies of particulate emissions from in-use New York City vehicles, Aerosol Sci. Technol., 38, 555-573, 2004.

CAM (Comisión Ambiental Metropolitana): Inventario de emisiones 2002 de la Zona Metropolitana del Valle de México, Secretaría del Medio Ambiente, Gobierno de México, México, 2004.

CARB, (California Air Resources Board): The California Almanac of Emissions and Air Quality - 2005 Edition, available at http: //www.arb.ca.gov/ei/emissiondata.htm, 2005.

de Foy, B., Caetano, E., Magaña, V., Zitácuaro, A., Cárdenas, B., Retama, A., Ramos, R., Molina, L. T., and Molina, M. J.: Mexico City basin wind circulation during the MCMA-2003 field campaign, Atmos. Chem. Phys., 5, 2267-2288, 2005, http://www.atmos-chem-phys.net/5/2267/2005/.

de Foy, B., Clappier, A., Molina, L. T., and Molina, M. J.: Distinct wind convergence patterns due to thermal and momentum forcing of the low level jet into the Mexico City basin, Atmos. Chem. Phys., 6, 1249-1265, 2006a.

de Foy, B., Varela, J. R., Molina, L. T., and Molina, M. J.: Rapid ventilation of the Mexico City basin and regional fate of the urban plume, Atmos. Chem. Phys., 6, 2321-2335, 2006b.

Dunlea, E., Volkamer, R., Johnson, K. S., Zavala, M., Molina, L. T., Molina, M. J., Lamb, B., Allwine, E., Rogers, T., Knighton, B., Grutter, M., Gaffney, J. S., Marley, N. A., Herndon, S. C., Zahniser, M. S., Jayne, J., Shorter, J. H., Wormhoudt, J. C., and Kolb, C. E.: Nitrogen Oxides (NOy) in the Mexico City Metropolitan Area, American Geophysical Union, Fall Meeting 2004, abstract \#A14A-05, 2004.
Fraser, M. P. and Cass, R. G.: Detection of excess ammonia emissions from in-use vehicles and the implications for fine particle control, Environ. Sci. Technol., 32, 1053-1057, 1998.

Gakenheimer, R., Molina, L. T., Sussman, J., Zegras, C., Howitt, A., Makler, J., Lacy, R., Slott, R. S., Villegas, A., Molina, M. J., and Sánchez, S.: The MCMA transportation system: Mobility and air pollution, in: Air Quality in the Mexico Megacity: An Integrated Assessment, edited by: Molina, L. T. and Molina, M. J., Kluwer Academic Publishers, Dordrecht, The Netherlands, pp. 213-284, 2002.

García, A., Volkamer, R., Molina, L. T., Molina, M. J., Samuelsson, J., Mellqvist, J., Galle, B., Herndon, S., and Kolb, C. E.: Separation of emitted and photochemical formaldehyde in the Mexico City Metropolitan Area using a statistical analysis and a new pair of gas-phase tracers, Atmos. Chem. Phys., 6, 4545-4557, 2006, http://www.atmos-chem-phys.net/6/4545/2006/.

Giechaskiel, B., Ntziachristos, L., Samaras, Z., Scheer, V., Casati, R., and Vogt, R.: Formation potential of vehicle exhaust nucleation mode particles on-road and in the laboratory, Atmos. Environ., 39, 3191-3198, 2005.

Herndon, S. C., Shorter, J. H., Zahniser, M. S., Wormhoudt, J., Nelson, D. D., Demerjian, K. L., and Kolb, C. E.: Real-Time Measurements of $\mathrm{SO}_{2}, \mathrm{H}_{2} \mathrm{CO}$, and $\mathrm{CH}_{4}$ emissions from in-use curbside passenger buses in New York City using a chase vehicle, Environ. Sci. Technol., 39, 7984-7990, 2005a.

Herndon, S. C., Jayne, J. T., Zahniser, M. S., Worsnop, D. R., Knighton, B., Alwine, E., Lamb, B. K., Zavala, M., Nelson, D. D., McManus, J. B., Shorter, J. H., Canagaratna, M. R., Onasch, T. B., and Kolb, C. E.: Characterization of urban pollutant emission fluxes and ambient concentration distributions using a mobile laboratory with rapid response instrumentation, Faraday Discuss., 130, 327-339, 2005b.

Herndon, S. C., Shorter, J. H., Zahniser, M. S., Nelson Jr., D. D., Jayne, J. T., Brown, R. C., Miake-Lye, R., Waitz, I., Silva P., Lanni, T., Demerjian, K. L., and Kolb, C. E.: $\mathrm{NO}$ and $\mathrm{NO}_{2}$ emission ratios measured from in-use commercial aircraft during taxi and takeoff, Environ. Sci. Technol., 38(22), 6078-6084, 2004.

Huai, T., Durbin, T. D., Rhee, S. H., and Norbeck, J. M.: Investigation of emission rates of ammonia, nitrous oxide and other exhaust compounds from alternative fuel vehicles using a chassis dynamometer, International Journal of Automotive Technology, 4(1), 9-19, 2003.

Jiang, M., Marr, L. C., Dunlea, E. J., Herndon, S. C., Jayne, J. T., Kolb, C. E., Knighton, W. B., Rogers, T. M., Zavala, M., Molina, L. T., and Molina, M. J.: Vehicle fleet emissions of black carbon, polycyclic aromatic hydrocarbons, and other pollutants measured by a mobile laboratory in Mexico City, Atmos. Chem. Phys., 5, 3377-3387, 2005,

http://www.atmos-chem-phys.net/5/3377/2005/.

Jiménez, J. L., Nelson, D. D., Zahniser, M. S., Koplow, M. D., and Schmidt, S. E.: Characterization of on-road vehicle NO emissions by a TILDAS remote sensor, J. Air Waste Manage. Assoc., 49, 463-470, 1999.

Jiménez, J. L., McManus, J. B., Shorter, J. H., Nelson, D. D., Zahniser, M. S., Koplow, M., McRae, G. J., and Kolb, C. E.: Cross road and mobile tunable infrared laser measurements of nitrous oxide emissions from motor vehicles, Chemosphere - Global Change Science, 2, 397-412, 2000.

Johnson, K. S., Zuberi, B., Molina, L. T., Molina, M. J., Iedema, 
M. J., Cowin, J. P., Gaspar, D. J., Wang, C., and Laskin, A.: Processing of soot in an urban environment: case study from the Mexico City Metropolitan Area, Atmos. Chem. Phys., 5, 30333043, 2005,

http://www.atmos-chem-phys.net/5/3033/2005/.

Kado, N. Y., Okamoto, R. A., Kuzmicky, P. A., Kobayashi, R., Ayala, A., Gebel, M. E., Rieger, P. L., Maddox, C., and Zafonte, L.: Emissions of toxic pollutants from compressed natural gas and low sulfur diesel-fueled heavy-duty transit buses tested over multiple driving cycles, Environ. Sci. Technol., 39(19), 76387649, 2005.

Kirchstetter, T. W., Singer, B. C., Harley, R. A., Kendall, G. R., and Traverse, M.: Impact of California reformulated gasoline on motor vehicle emissions. 1. Mass emissions rates, Environ. Sci. Technol., 33, 318-328, 1999.

Kittelson, D., Johnson, J., Watts, W., Wei, Q., Drayton, M., Paulsen, D., and Bukowiecki, N.: Diesel Aerosol Sampling in the Atmosphere, Society of Automotive Engineers, paper number SAE 2000-01-2212, 2000.

Kolb, C. E., Herndon, S. C., McManus, J. B., Shorter, J. H., Zahniser, M. S., Nelson, D. D., Jayne, J. T., Canagaratna, M. R., and Worsnop, D. R.: Mobile laboratory with rapid response instruments for real-time measurements of urban and regional trace gas and particulate distributions and emission source characteristics, Environ. Sci. Technol., 38, 5694-5703, 2004.

Molina, M. J. and Molina, L. T.: Megacities and atmospheric pollution, J. Air Waste Manage. Assoc., 54(6), 644-680, 2004.

Molina, L. T., Molina, M. J., Slott, R. S., Kolb, C. E., Gbor, P. K., Meng, F., Singh, R. B., Galvez, O., Sloan, J. J., Anderson, W. P., Tang, X. Y., Hu, M., Xie, S., Shao, M., Zhu, T., Zhang, Y. H., Gurjar, B. R., Artaxo, P. E., Oyola, P., Gramsch, E., Hidalgo, D., and Gertler, A. W.: Air quality in selected megacities, critical review complete online version, http://www.awma.org, 2004.

Molina, L. T. and Molina, M. J.: Clearing the air: a comparative study, in: Air Quality in the Mexico Megacity: An Integrated Assessment, edited by: Molina, L. T. and Molina, M. J., Kluwer Academic Publishers, Boston, 2002.

NARSTO, (North American Research Strategy for Tropospheric Ozone): Improving emissions inventories for effective air quality management across North America, a NARSTO assessment, NARSTO-05-001, 2005.

Pirjola, L., Parviainen, H., Hussein, T., Valli, A., Hameri, K., Aaalto, P., Virtanen, A., Keskinen, J., Pakkanen, T.A., Makela, T., and Hillamo, R. E.: "Sniffer" - A Novel tool for chasing vehicles and measuring traffic pollutants, Atmos. Environ. 34, 3625-3635, 2004.

Popp, P. J., Bishop, G. A., and Stedman, D. H.: Development of a high-speed ultraviolet spectrometer for remote sensing of mobile source nitric oxide emissions, J. Air Waste Manage. Assoc., 49, 1463-1468, 1999.

Rogers, T. M., Grimsruda, E. P., Herndon, S. C., Jayne, J. T., Kolb, C. E., Allwine, E., Westberg, H., Lamb, B. K., Zavala, M., Molina, L. T., Molina, M. J., and Knighton, W. B.: On-road measurements of volatile organic compounds in the Mexico City Metropolitan Area using proton transfer reaction mass spectrometry, Int. J. Mass Spectr., 252(1), 26-37, 2006.

Salcedo, D., Onasch, T. B., Dzepina, K., Canagaratna, M. R., Zhang, Q., Huffman, J. A., DeCarlo, P. F., Jayne, J. T., Mortimer, P., Worsnop, D. R., Kolb, C. E., Johnson, K. S., Zuberi,
B., Marr, L. C., Volkamer, R., Molina, L. T., Molina, M. J., Cardenas, B., Bernabé, R. M., Márquez, C., Gaffney, J. S., Marley, N. A., Laskin, A., Shutthanandan, V., Xie, Y., Brune, W., Lesher, R., Shirley, T., and Jimenez, J. L.: Characterization of ambient aerosols in Mexico City during the MCMA-2003 campaign with Aerosol Mass Spectrometry: results from the CENICA Supersite, Atmos. Chem. Phys., 6, 925-946, 2006,

http://www.atmos-chem-phys.net/6/925/2006/.

Schifter, I., Díaz, L., Mugíca, V., and López-Salinas, E.: Fuel-based motor vehicle emission inventory for the metropolitan area of Mexico City, Atmos. Environ., 39, 931-940, 2005.

Schifter, I., Díaz, L., Vera, M., Guzmán, E., and López-Salinas, E.: Fuel formulation and vehicle exhaust emissions in Mexico, Fuel, 83, 2065-2074, 2004.

Schifter, I., Díaz, L., Vera, M., Castillo, M., Ramos, F., Avalos, S., and López-Salinas, E.: Impact of engine technology on the vehicular emissions of Mexico City, Environ. Sci. Technol., 34, 2663-2667, 2000.

Shirley, T. R., Brune, W. H., Ren, X., Mao, J., Lesher, R., Cardenas, B., Volkamer, R., Molina, L. T., Molina, M. J., Lamb, B., Velasco, E., Jobson, T., and Alexander, M.: Atmospheric oxidation in the Mexico City Metropolitan Area (MCMA) during April 2003, Atmos. Chem. Phys., 6, 2753-2765, 2006,

http://www.atmos-chem-phys.net/6/2753/2006/.

Singer, B. C. and Harley, R. A.: A fuel-based inventory of motor vehicle exhaust emissions in the Los Angeles area during summer 1997, Atmos. Environ., 34, 1783-1795, 2000.

Shorter, J. H., Herndon, S., Zahniser, M. S., Nelson, D. D., Wormhoudt, J., Demerjian, K. L., and Kolb, C. E.: Real-time measurements of nitrogen oxide emissions from in-use New York City transit buses using a chase vehicle, Environ. Sci. Technol., 39, 7991-8000, 2005.

Stedman, D. H., Bishop, G. A., Aldrete, P., and Slott, R. S.: On-road evaluation of an automobile emission test program, Environ. Sci. Technol., 31, 927-931, 1997.

Vogt, R., Scheer, V., Casati, R., and Benter, T.: O-road measurement of particle emission in the exhaust plume of a diesel passenger car, Environ. Sci. Technol., 37, 4070-4076, 2003.

Volkamer, R., Molina, L. T., Molina, M. J., Shirley, T., and Brune, W. H.: DOAS measurement of glyoxal as an indicator for fast VOC chemistry in urban air, Geophys. Res. Lett., 32, L08806, doi:10.1029/2005GL022616, 2005.

Wenzel, T., Singer, B. C., and Slott, R. S.: Some issues in the statistical analysis of vehicle emissions, Journal of Transportation and Statistics, September issue 1-14, 2000.

Whitfield, J. K. and Harris, D. B.: Comparison of heavy-duty diesel emissions from engine and chassis dynamometers and on-road testing, in: Eighth CRC On-Road Vehicle Emissions Workshop, San Diego, CA., Coordinating Research Council, 1998.

Yanowitz, J., Graboski, M. S., Ryan, L. B., Alleman, T. L., and Mccormick, R. L.: Chassis dynamometer study of emissions from 21 in-use heavy-duty diesel vehicles, Environ. Sci. Technol., 33(2), 209-216, 1999.

Zahniser, M. S., Nelson, D. D., McManus, J. B., and Kebabian, P. K.: Measurement of trace gas fluxes using tunable diode laser spectroscopy, Philos. Trans. R. Soc. Lond., 351, 371-382, 1995. 